\title{
Hyman Minsky's financial instability hypothesis and the Greek debt crisis
}

\author{
Sergey Beshenov, Ivan Rozmainsky* \\ National Research University Higher School of Economics, St. Petersburg, Russia
}

\begin{abstract}
This article attempts to analyze the current debt crisis in Greece based on the financial instability hypothesis developed by Hyman Minsky. This article shows that the hypothesis provides an understanding of how an economy endogenously becomes "financially fragile" and thus prone to crises. The authors analyze how public and private sector behavior in the Greek economy led to the country's debt crisis. In particular, based on a sample of 36 Greek companies, the authors show that between 2001 and 2014, the majority of those companies had switched to fragile financial structures. Special attention is devoted to the negative consequences of applying the neoclassical doctrine of "austerity measures" in Greece as the principal "anti-crisis" concept of mainstream economic science.

(C) 2015 Non-profit partnership "Voprosy Ekonomiki”". Hosting by Elsevier B.V. All rights reserved.
\end{abstract}

JEL classification: B59, E12, E32, E44, E52.

Keywords: financial instability hypothesis, Minsky, Post-Keynesianism, financial fragility, Greek crisis, austerity measures.

\section{Introduction}

The majority of this article was written last summer, when Greece's national debt to European banks and the IMF was $185 \%$ of its GDP, or more than EUR 300 billion. Greece was scheduled to pay back EUR 1.55 billion to the IMF on June 30, but was unable to do so due to its catastrophic liquidity gap. On June 29, the country instituted capital flow controls. For three weeks (until July 20), every bank was closed throughout Greece, while the holidays on the Athens Stock Exchange were

\footnotetext{
The updated English version of the article published in Russian in Voprosy Ekonomiki, 2015, No. 11, pp. 120-143.

* Corresponding author, E-mail address: irozmain@yandex.ru.

Peer review under responsibility of Voprosy Ekonomiki.
} 
extended for two weeks, until August 3. On July 5, a poll was taken on whether to compromise with international creditors, and the majority of the country's population is known to have said no. This rejection of the proposed measures meant that the "technical default" would very likely become a recognized fact. For over two weeks, the country's potential exit from the Eurozone was a priority agenda item for the Old World politicians and economists, as well as many others. The issue was removed from the agenda on July 17, when the Eurozone countries signed a tentative agreement to lend EUR 86 billion to Greece for a three-year term, after which discussions of the "Hellenic economy" lost some of their fervor. There is no guarantee, however, that Greece will not leave the Eurozone at some point.

For many years, Greek economic issues have occupied the front pages of various economic and financial publications which have suggested a number of theoretical and practical explanations for the problem. In our opinion, the discussions of this crisis would be far more fruitful if the scientific perspective of their participants went beyond mainstream economic theory. One alternative is the financial instability hypothesis developed by Hyman Minsky, an outstanding American economist (1919-1996). According to this hypothesis, a capitalist economy endogenously promotes such financial relationships between economic entities that make it prone to debt crises.

This article reviews the main aspects of Minsky's concept, its comparison with competing approaches and, most importantly, its application to the current Greek debt crisis. We will attempt to prove that the financial instability hypothesis provides the best explanation for why Greece is now in a state of default.

\section{Minsky's view on Keynes's theoretical legacy and on money, financial relationships, and investments}

Minsky was a leading advocate of Post-Keynesianism, one of the main heterodox ${ }^{1}$ schools of modern economic thought. Developing the underlying principles of the Post-Keynesian school, Minsky showed that Keynes's main ideas had been distorted, while many of them were simply omitted by J. R. Hicks, P. Samuelson, and other proponents of traditional Keynesianism. ${ }^{2}$

"Decision-making under uncertainty, the cyclical nature of the capitalist process, and financial relations of an advanced capitalist economy" (Minsky, 1975, p. ix) are what Minsky referred to as the elements of Keynes's theory lost in traditional Keynesianism. The connection between these elements can be described as follows. A capitalist economy, as a system based on using long-term assets in production and circulation exists in a historical time where "its past is given and cannot be changed, and... its future is uncertain and cannot be known."3 Therefore, one cannot move from the future to the past in this time, unlike in logical time.

\footnotetext{
${ }^{1}$ Another term is unorthodox. For the differences between mainstream and heterodoxy, see Rozmainsky (2008).

${ }^{2}$ It is the models of traditional Keynesians that form the basis for introductory macroeconomics courses, and it is according to these models that Keynesianism is judged. At the same time, it should be remembered that those models do not fit well into the modern mainstream - although they are slightly better than the theory of Keynes himself or Post-Keynesian elaborations (Rozmainsky, 2008) — primarily because many of them are not based on microeconomic foundations.

3 The quote belongs to B. Moore and is taken from Arestis (1988, p. 42).
} 
To provide protection from the uncertainty inherent in historical time, money is created as an absolutely liquid and reliable asset. However, "money... cannot be readily produced" (Keynes, 1978, p. 301). ${ }^{4}$ Consequently, increasing (decreasing) the demand for money by decreasing (increasing) the demand for productive assets "responsible" for national income and employment will lead to a recession (recovery) in an economy. This lays the basis of the cyclical nature of a capitalist economy. This cyclicity is aggravated by the complex financial relationships that enable greater investments during a recovery phase, while resulting in a heavy debt burden for investors during a recession. Thus, Keynes's theory asserts a cyclical instability inherent in capitalist economies. Those are the very aspects that were lost in traditional Keynesian macroeconomic theory, while the theory of Keynes himself ${ }^{5}$ wound up as just a specific case of the neoclassical theory.

These circumstances encouraged Minsky to assert an inherent relationship between traditional Keynesianism and neoclassical theory. He argued that both approaches were "based upon a barter paradigm — the image is of a yeoman or craftsman trading in a village market" (Minsky, 1975, p. 57). His own approach "rests upon a speculative financial paradigm - the image is of a banker making his deals on a Wall Street" (Minsky, 1975, p. 58). ${ }^{6}$

Minsky also noted that in some of his articles (Keynes, 1937, 1939), published after General Theory, the British economist described the processes of accumulating fixed capital and its financing, thereby laying the foundation for the endogenous money supply theory. According to Keynes, the acquisition of capital is immediately preceded by a businessman receiving the money ("finance" according to his terminology) from financial institutions. The latter's creation of money by providing credit to investor firms serves as a necessary condition for investment. However, Keynes did not expressly formulate this thesis, which is only implied in his theory. Minsky stressed this fact, noting that "in a capitalist economy, money is tied up with the process of creating and controlling capital assets" (Minsky, 1986, p. 223). According to Minsky, "creating money is part of the mechanism by which a surplus is forced and allocated to the production of particular investment output" (Minsky, 1986, p. 224). To summarize, money is an asset created within an economy, i.e. endogenously, to acquire productive assets (first of all, fixed capital). ${ }^{7}$

\footnotetext{
${ }^{4}$ This thesis is correct with respect to commodity money. Credit money is often characterized by endogeneity (see below), which is why this assertion cannot be applied to it. It is, however, characterized by a zero labor intensity, just like commodity money. This is why the train of thought that follows reflects the reality of an economy with credit money (Rozmainsky, 2006, p. 21).

${ }^{5}$ From the point of view of Minsky and other leading Post-Keynesians (P. Davidson, F. Carvalho, L. R. Wray, etc.), the most significant elements of the Keynesian school-and most underestimated in traditional Keynesianism - are Chapters 12 and 17 of his General Theory of Employment, Interest and Money. See in particular: Davidson (1972), Carvalho (1992).

${ }^{6}$ Minsky first generalized his ideas concerning the correct interpretation of Keynes in his John Maynard Keynes (Minsky, 1975) and then supplemented them in his main work Stabilizing an Unstable Economy (Minsky, 1986). Before him, Dillard (1948) and Davidson (1972) were presumably the only ones who dared to provide an integral, "unorthodox" interpretation of Keynes's theory.

7 It should be noted that the endogenous money supply concept itself was not invented by Minsky. Many PostKeynesians wrote that money is created endogenously in a modern capitalist economy (Arestis, 1988; Chick, 1992; Davidson, 1972; Wray, 1992). However, when analyzing the endogenous factors, they only pointed to the need to create working capital (expenses for wages, raw materials and taxes) or to independent pricing by firms in the oligopolistic structures. Minsky's contribution is that he identified a relationship between money supply dynamics combined with its structural changes due to the emergence and spread of more liquid money aggregates, on the one hand, and the process of accumulating fixed capital through productive investments, on the other.
} 
In the 1950s, Minsky (1957) showed that, when faced with insufficient reserves, financial institutions satisfy the demand by firms for investment-financing money through financial innovations. For example, executing transactions involving repurchase agreements (selling and then buying a debt obligation) results in the seller immediately receiving money that can be loaned. Later, Minsky and other Post-Keynesians pointed to important financial innovations: using deposit certificates and foreign exchange loans, securitization (converting bank loans into securities), and off-balance sheet activity. This latter type of innovation may be expressed, for example, through issuing "facilities" to several firms in the form of an obligation to provide loans in certain amounts upon their demand, etc. (Chick, 1992). This type of financial evolution reduces the efficiency of the central bank's monetary policy and enhances the endogeneity of the money supply.

Minsky built on the ideas contained in Chapter 17 of the General Theory, showing that the value of any long-term asset is determined by its own rate of interest. Simply put, this indicator is the sum of all benefits received from an asset, less its carrying costs. Those benefits include not only monetary proceeds (pecuniary yield) but also the implicit advantages of owning it, e.g., high liquidity. It should be stressed that all of the above benefits are anticipated and not actual values. ${ }^{8}$

According to Minsky, an asset's own rate of interest is none other than the demand price for that asset, reflecting its attractiveness as perceived by a particular investor (or the market as a whole). There is also the asset's supply price. It is nothing more than the price of its production and is determined by the sum of the average cost and (affected by the market power) markup, as is the case with imperfect competition, which was usually assumed by Minsky and other PostKeynesians. Thus, a capitalist economy is characterized by two price levels. One of these levels depends on the conditions of asset production, while the other depends on the capitalized value of anticipated income from their use. The amount of investment in an asset is determined by the relationship between the demand and supply prices. Strictly speaking, investments in an asset will be made only if the demand price is equal to or exceeds the supply price.

However, these price levels are not the only investment factors. Unless firms seek the assistance of financial institutions and the market to finance their investments, there is a serious limitation on investments in the form of internal financial resources (funds). Whenever external financing is used for investments, additional determinants of investments appear, i.e., the lender risk and the borrower risk. ${ }^{9}$ The former risk relates to the concerns of banks and other financial institutions that the borrower might not be able to repay the debt. The latter risk is associated with the borrower firm's concerns that it might not be able to repay the loan. Both risks are directly correlated to financial leverage, i.e., the ratio of an economic entity's debt (in this case, the investor firm) to its equity. Increasing the amount of investments financed through debt will sooner or later entail an increase in the lender and borrower risks, which will limit their value.

Thus, the function of investments includes factors reflecting the uncertainty of the future and the degree of pessimism or optimism by economic entities.

\footnotetext{
${ }^{8}$ Keynes himself did not put particular stress on the differences between values for these two types.

9 The terms "borrower risk" and "lender risk" were first suggested by Keynes (1978, p. 108-110) in Chapter 11 of the General Theory. However, they went unnoticed by his immediate followers.
} 
It is these factors, rather than the determinants associated with the current top productivity of capital (as in neoclassical theory), that play an important part in determining the amount of investments. Furthermore, the variables in the investment function reflecting the financial condition of investors are equally important. Thus, the amount of investment by a firm depends on its liability structure.

\section{The financial instability hypothesis in explaining debt crises}

The financial instability hypothesis (hereinafter referred to as the FIH) ${ }^{10}$ is based on Minsky's theories of money, financial evolution and investment, as well as on Fisher's (1933) concept of debt deflation. ${ }^{11}$ According to this concept, the downward trends in an economy are aggravated by lowering prices (supply prices in Minsky's terms), as such a reduction makes real debt a heavier burden, leading to insolvency and bankruptcy for many production units.

The FIH is the basis for the "theory of how a capitalist economy endogenously generates a financial structure which is susceptible to financial crises" (Minsky, 1983, p. 289-290). A financial structure here is "the market interactions between borrowers and lenders and the balance sheets of non-financial firms, intermediaries and households that reflect these interactions" (Pollin, 1994, p. 97). According to the FIH, economic trends are largely determined by the way in which firms finance their fixed capital investments. In the beginning of the increasing stage of the business cycle (recovery phase), hedge finance prevails, where current monetary proceeds are sufficient for firms to repay debt including interest. This type of financing is, to a great extent, dependent on the firm's heavier reliance on internal financial sources rather than on external funds. An explanation is that during the recovery phase, the recent depression is still fresh in the memories of economic entities. This is why lender and borrower risks are still high.

However, those memories fade gradually, particularly because national income created through hedge investments is increasing. Lender and borrower risks are decreasing. As Keynes (1978, p. 210) wrote, "during a boom the popular estimation of the magnitude of both these risks, both borrower's risk and lender's risk, is apt to become unusually and imprudently low". As a result, firms actively switch to external financing for capital investments. Over time, a situation arises where the monetary proceeds for many firms are only sufficient to pay interest, but are not enough for the repayment of the respective principals. To save themselves from bankruptcy, those firms are force to take out new loans to repay the old ones. Minsky called this speculative finance. Growing interest rates or falling money proceeds for firms inevitably transform speculative finance into Ponzi finance, ${ }^{12}$ where those proceeds are inadequate even for regular interest payments. The only way out of this situation is to increase the amount of debt to repay old loans.

\footnotetext{
10 Another common term is the financial fragility hypothesis.

11 Minsky believed that his financial instability hypothesis was created under the influence of ideas by Keynes, Fisher, and also Simons (1936, p. 130) who was the first to note the dangers associated with the endogenous creation of money through short-term financing of long-term investment projects. On Minsky's earlier studies, see Toporowski (2008).

12 This financing technique was named after a Boston banker, Charles Ponzi, who, immediately after the First World War, engaged in financial speculations similar to those that were applied decades later in post-Soviet Russia by financial companies, such as MMM.
} 
While speculative finance is characteristic of the boom phase, Ponzi finance leads to recession. This is because, sooner or later, firms using this type of financing will become unable to obtain new loans, either due to increased lender risks (reflecting the pessimism of financial institutions) or due to the general lack of financial resources (money and its substitutes) in the economy. If firms start to sell their productive assets to receive those resources, this will lead to a decrease in their demand price, investment levels, and, naturally, to an economic crisis. Such crisis can be made worse by excessively high borrower risk (resulting in lower investments by firms than the amount that would have been financed based on internal sources) and, particularly, by the demand price for productive assets falling below the supply price. This is because the latter case will make the investment process halt altogether.

Thus, the most important reason for periodic debt crises is the systematic inability of firms to repay their debts in the financial sector. This is an important conclusion of the FIH. Another is that, during a business cycle, the financial system becomes more and more fragile, i.e. the liquidity of an economic entity balance sheet decreases. In other words, a business cycle can be perceived as a phenomenon related to changes in the fragility of an economy (Carvalho, 1992, p. 153).

Minsky generalized the basic provisions of the FIH as follows. "The first theorem of the financial instability hypothesis is that the economy has financing regimes under which it is stable and financing regimes in which it is unstable. The second theorem of the financial instability hypothesis is that over periods of prolonged prosperity, the economy transits from financial relations that make for a stable system to financial relations that make for an instable system" (Minsky, 1992, p. 7-8). Thus, the FIH demonstrates that "stability — or tranquility — in a world with a cyclical past and capitalist financial institutions is destabilizing” (Minsky, 1985, p. 37).

\section{The financial instability hypothesis and implications for economic policy}

Minsky argued for active macroeconomic and institutional intervention by the government in the economy. He treated the government's macroeconomic role, first of all, as preventing a financial collapse during recessions and depressions, i.e. maintaining monetary proceeds for production and financial units. In his opinion, for this purpose, expansionist fiscal and monetary policy should be pursued during recessions. The former increases income for the private sector through increasing aggregate demand, enabling many firms to repay their debts and avoid bankruptcy. The latter increases liquidity of the financial sector, enabling financial institutions facing bad debts or a mass withdrawal of customer deposits to "stay afloat." According to Minsky, this type of intervention saved Western countries from a new Great Depression by preventing debt deflation from the 1970s through the 1990s. ${ }^{13}$ On the other hand, stagflation was the price to pay for that prevention.

However, a macroeconomic policy cannot change the underlying parameters of advanced modern capitalist economies which make them prone to instability. The problem is that a repeated policy of government stimulus lulls both

\footnotetext{
13 As demonstrated below, the currently popular austerity measures, inspired by the neoclassical orthodoxy, may induce a condition similar to the Great Depression, as exemplified by the Greek economy in the 2010s.
} 
firms and banks into a false sense of security. As more and more investment projects are successfully implemented, economic entities will become more and more reckless. As Minsky (1985, p. 52) noted, "once the doctrine of salvation through investment becomes deeply ingrained into our political and economic system, the constraints on foolish investments are relaxed. This is especially so if the government stands ready to guarantee particular investors or investment projects against losses." In the Post-Keynesian tradition, this phenomenon is usually called the Minsky paradox.

According to Minsky, a capitalist economy can be saved from instability through the government's institutional policy. This policy should consist, first of all, of stimulating changes to the aggregate demand and production technology structure: the share of consumption in the aggregate demand should increase, while technology should become more labor intensive. He suggested that "an economy that is oriented towards the production of consumption goods by techniques that are less capital intensive... will be less susceptible to financial instability and inflation" (Minsky, 1985, p. 53). Second, this type of policy should require a simpler financial system, which would be achieved mainly through limiting short-term lending for long-term investment projects, i.e. through restricting speculative and Ponzi finance. As Minsky (1980, p. 520) noted, "the financing of capital asset ownership and investment is the critical destabilising phenomenon."14 While all of these recommendations were suggested as early as the 1980s, they remain relevant today.

Minsky died in 1996, but his ideas were adopted by his students around the world. ${ }^{15}$ The crisis that hit the world 12 years later resulted in active support for his ideas (Rozmainsky, 2009; Wray, 2011; Wray and Tymoigne, 2008 ${ }^{16}$ ). From the perspective of Minsky's theory, the main reasons for the crisis are obvious. The long growth that was observed at the turn of the century and was caused, in particular, by the specific combination of the development of the "new economy" (related to telecommunications, Internet, etc.), heavy financial innovation and globalization processes, increased the financial fragility of the entire global economy. This boom caught economic entities off guard around the world, and they took out many "doubtful" loans and became illiquid and insolvent. Quite logically, the "payback" was the global crisis. Thus, according to Minsky, the current financial and economic crisis is a consequence of the functioning and evolution of the institutions belonging to the modern advanced capitalist economy. Overcoming this crisis and preventing it from repeating is impossible without

\footnotetext{
${ }^{14}$ It should be noted that the idea of financial fragility caught the attention of mainstream economists, represented by Neo-Keynesians such as Joseph Stiglitz, Ben Bernanke, etc. This led to the publication of famous articles (Bernanke and Gertler, 1990; Greenwald and Stiglitz, 1993) that are considered pioneering works for some reason, although it was Minsky who first studied the concept of financial fragility and its role. Moreover, Neo-Keynesians interpreted financial fragility in their accustomed manner as a consequence of asymmetric information. Those authors also did not appeal in any way to uncertainty, the special role of money, financial evolution or investment (Wray and Tymoigne, 2008, p. 3).

15 The authors of many papers applied the FIH in their analyzes of financial crises in Southeast Asia (Arestis and Glickman, 2002; Kregel, 1998; Shroeder, 2002), Latin America (Cruz et al., 2006; De Paula and Alves, 2000), the Middle East (Dufour, 2006), and Eastern Europe (Bezemer, 2001).

16 L. Randall Wray and his colleagues are mainly associated with the Modern Money Theory (MMT). But this in no way contradicts their affiliation with Post-Keynesianism, as this theory is one attempt to develop the concept of endogenous money, while Wray himself shows a close connection between the MMT and Minsky's approach. For more, see Wray (2014).
} 
profoundly reforming those institutions. Some areas of focus within such reforms might include restricting the securitization and development of derivative financial instruments, as well as the short-term financing of long-term investment projects. It is also desirable to pose stricter requirements on the liquidity of financial institution balance sheets.

\section{An analysis of the Greek debt crisis and the financial instability hypothesis: The public sector}

Some countries have not yet recovered from the global crisis and their situation continues to worsen. Greece is one example. The country's total dependence on external creditors, and the fact they share a currency zone with the latter, makes the case of Greece unique. The creditors include, first of all, the so-called Troika, i.e., the International Monetary Fund (IMF), the European Commission, and the European Central Bank. Against the backdrop of the overall Eurozone recession in early 2008, Greece, with its budget balance deficit and a national debt exceeding its GDP, found it difficult to continue to fulfill its financial obligations. The customary macroeconomic practice in a depressed economy includes measures inspired by traditional Keynesianism, such as stimulation through increased spending in the public sector and reducing interest rates. However, the governments of most Western countries chose a completely different practice, inspired by the neoclassical doctrine, i.e., a program of austerity measures based on the idea of reducing public spending on infrastructure and social projects combined with increased taxes and various duties. Since the beginning of the 2010s, similar measures for economic "recovery" were supported by certain groups in the economic community, including the research departments from the institutions of the Troika.

Alberto Alesina is currently one of the most notorious advocates of austerity measures. He analyzed panel data for all cases of the application of fiscal policies in developed countries from 1970 to 2007, and concluded that reducing spending leads to economic growth, rather than recession (Alesina and Ardagna, 2009). He and those who adopted his findings argue that the reason for successfully reducing spending lies in greater certainty associated with the stability of the government's budget. Greater certainty, according to Alesina, brings about positive effects that mitigate the consequences of reduced spending. Austerity measures have been defended by Trichet (2010), former ECB President, and Olivier Blanchard, the IMF's former chief economist. It should be noted that, unlike Alesina, Blanchard did not argue that austerity measures could promote economic growth; however, he believed that the fiscal multiplier for Greece was considerably below 1 (Plumer, 2012). In other words, the budget deficit can be reduced without output falling catastrophically.

The debt threshold was another argument in favor of creditors. This concept was put forward by Reinhart and Rogoff (2009). In their book entitled This Time Is Different, the authors carried out an empirical study of a wide array of macroeconomic data, coming to the conclusion that an economy cannot grow when debt is $90 \%$ or more of GDP. Not surprisingly, advocates of austerity measures relied on this conclusion. This was especially true of creditors who were interested in getting their money back as soon as possible. 
The empirical component of the aforementioned papers attracted analysts wishing to study the technical aspects of this issue in more detail. Reinhart and Rogoff's study was harshly criticized by a group of scientists from Amherst University (Massachusetts). Having reproduced the database, they managed to find that "selective exclusion of available data, and unconventional weighting of summary statistics lead to serious errors that inaccurately represent the relationship between public debt and GDP growth among 20 advanced economies in the postwar period," (Herndon et al., 2014, p. 257). Strange as it may seem, the irregularities in Alesina's paper and the IMF's miscalculations of financial multipliers were revealed by the IMF (2012) itself. Notably, in the first case, it was done indirectly: a detailed analysis of austerity measures in countries where they had a minimal impact ${ }^{17}$ called into question Alesina and Ardagna's work and findings.

Considering the reasons for the success or failure of austerity measures in each particular country falls beyond the scope of this paper. Our objective is to study the appropriateness of austerity measures in the Greek economic situation, and the consequences of those measures. Instead of the empirical relationships suggested by advocates of spending cuts, we will analyze the Greek economy from the perspective of the Post-Keynesian theory of business cycles, i.e., Minsky's financial instability hypothesis.

As shown above, Minsky pointed to accumulating fragility in the private sector, where the key role belongs to corporate borrowers and lending banks whose motives become detrimental to the economy over time. Our objective is to bring the traditional vision of the hypothesis up to the international level: apply the FIH at the Eurozone level and essentially consider several economies as a single economic system. ${ }^{18}$ Countries in the Eurozone, with no territorial borders or customs barriers, but with a single currency and a single monetary policy regulator in the form of the ECB, form an economy whose characteristics are very similar to those of a federal economy.

However, the main difference is the absence of a single fiscal institution or political differentiation. By applying Minsky's hypothesis, it becomes evident that, similar to borrowing companies, the Eurozone has borrowing countries, while the functions of creditors at the international level are performed by lending countries. Since the creation of the Eurozone, Germany and France, as countries with more developed financial markets and economies, were actively lending to countries that were "catching up," i.e., Italy, Portugal, Spain, and, of course, Greece.

In further keeping with the hypothesis, the economic boom in the Eurozone encouraged investors to increase their investments in countries with unrealised economic potential and, accordingly, higher returns. Thus, Greece enjoyed a huge inflow of capital that on the one hand supported its economic upswing, but on the other hand led to increased financial leverage which, based on the FIH, reflects the accumulation of financial fragility. However, while superfluous lending to Greece had been perceived as normal until 2008, the global crisis abruptly changed the attitude towards that country's debt. The heightened uncertainty in the European market made investors reconsider the risk profiles of their investments, which led to di-

\footnotetext{
17 For example, the steep rise in stock market indicators in Finland during the early 2000s determined the GDP increase (see IMF, 2010, p. 119).

18 This paper used the methodology to be found in: Argitis and Nikolaidi (2014).
} 
sastrous consequences for Greece. Now we will consider the changes in the Greek economy chronologically, with a view towards substantiating the FIH.

As a member of the EU, Greece, not unlike other EU countries, hurried to integrate into the Eurozone. Joining a single-currency system promised a great number of advantages at that time, such as economic growth due to reduced transaction costs. To join the Eurozone, Greece had to meet the so-called Maastricht criteria, which included "reference" levels of inflation, the national budget deficit, national debt, long-term interest rates, and the exchange rate. Greece succeeded in meeting those criteria and in June 2000, the European Council approved its accession. The country officially became a member of the Eurozone on January 1, 2001. It was only later that Greece's price for meeting the Maastricht criteria became evident. After the 2004 audit requested by the new Greek government, Eurostat (2004) discovered that some indicators had been understated, particularly the national debt and budget deficit. It should also be noted that Greece had engaged in dubious transactions with Goldman Sachs to conceal its debts (Wray, 2011).

The expected economic growth, as the Eurozone member countries had planned, did happen: Greece became one of the fastest-growing economies in the Eurozone. Its GDP growth rate reached 6.6\% in 2003 and 5.8\% in 2006. However, that economic growth was accompanied by a budget deficit and accumulation of national debt, which the country later found difficult to repay. Greece's basic budget parameters and macroeconomic indicators are presented in Fig. 1.

The high budget deficit remained for 14 years after Greece joined the Eurozone. Between 2001 and 2007, it was approximately 5\% on average, whereas the GDP growth rate, that high, was not sufficient to reduce the national debt, which continued to rise. Moreover, it should be taken into account that at the time Greece acceded to the single currency, the country's national debt was already almost equal to its GDP, ${ }^{19}$ making the Greek economy vulnerable to external and internal shocks from the very beginning. Despite the debt overload, investments continued to flow into the Greek economy, and markets enjoyed a consumption boom. In 2008, the situation changed dramatically; with business activity declining throughout the Eurozone, the Greek economy fell into recession (GDP contracted by $0.4 \%$ ) and the budget deficit climbed to $9.9 \%$, which forced the government to increase the debt. Between 2008 and 2014, the ratio of the national debt to real GDP rose by 62 percentage points, while GDP remained negative and the budget deficit in double-digits throughout those years (except for 2014). In view of these indicator trends, the Greek economic crisis appears to be a classical example of the FIH. The government simply did not receive enough revenue to finance its debt and was left with no choice but to continue borrowing from lending countries. Thus, we believe that when it joined the Eurozone, Greece was already following a speculative finance scheme, but with the outbreak of the global crisis in 2008, the country had to turn to Ponzi finance, inducing further debt deflation. Below, we will try to explain the reasons for such a protracted crisis and, particularly, the debt deflation.

The 2008 crisis presumably triggered the events which ensued across the entire global economy. Beginning in the U.S., the financial crisis engulfed other countries, including those in the Eurozone. Financial instability, higher risks, and

\footnotetext{
19 On the ESA95 methodology, see Eurostat (2004).
} 


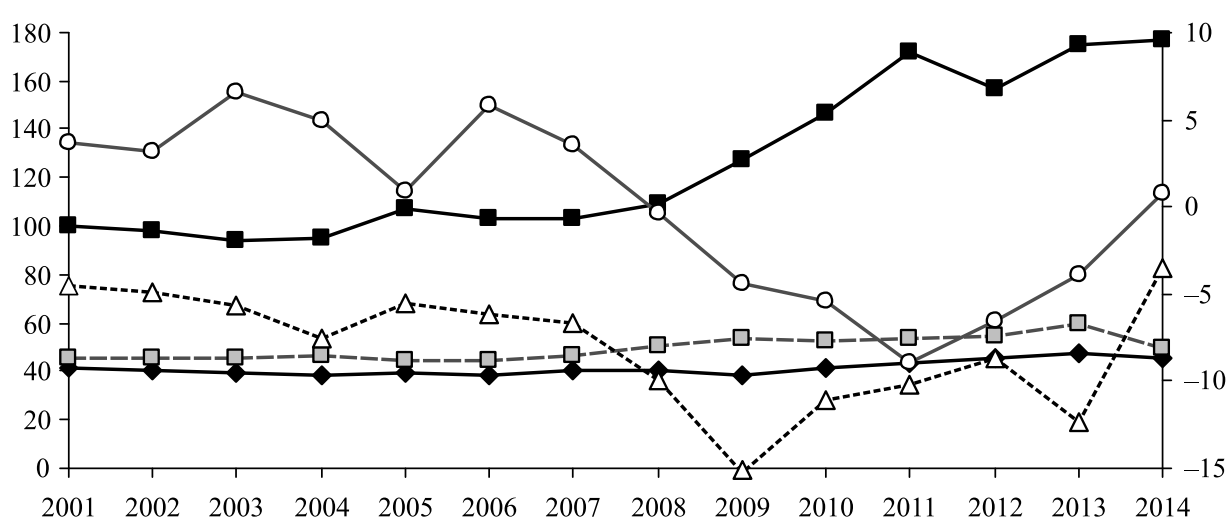

$$
\begin{array}{ll}
\longrightarrow \text { National income } & -\triangle-- \text { National budget balance (right-hand scale) } \\
-\square-\text { Government spending } & - \text { - National budget balance (right-hand scale) } \\
\rightarrow-\text { National debt } &
\end{array}
$$

Fig. 1. Greek national budget balance, real GDP and national debt (\% of GDP).

Source: Compiled by the authors based on FRED economic data (https://research.stlouisfed.org/fred2).

falling demand and investments resulted in an economic recession. Having overcome the 2008 and 2009 turbulence, the Eurozone faced a debt crisis. Borrowing countries ended up in distress after the global financial crisis, which also affected lending countries as the risk of default increased.

Between the end of 2008 and the beginning of 2013, there was apparently a strong correlation between bond interest rates and Greece's national debt. As the graph shows, the changes in the interest rate "outstripped" the debt increase (Fig. 2). On the one hand, investors who were worried about Greece's growing debt were unwilling to lend to the country on old terms, which led to higher interest rates and lower demand for the country's sovereign bonds. On the other hand, rising interest rates rendered the country unable to "break away" from the debt. The forecast of Greece's debt became self-fulfilling, and debt deflation arrived when asset prices dropped faster than the debt was repaid. In our case, the asset is Greece's debentures, which have been declining in value continuously since 2009. Thus, Greece was caught in a "debt spiral": while trying to repay its debts, it only ended up increasing them, because the cost of borrowing did not allow it to refinance the debt efficiently.

One possible way out of the spiral was through considerable external aid in the form of cheap liquidity provided by the Eurozone's stabilizing institutions. However, this solution was not very obvious for the institutions themselves. Nevertheless, certain measures were taken. A few allocations were made, and debts were restructured and written off. The overall amount of support from 2010 to 2014 was over EUR 200 billion (Waterfield, 2014). However, this enormous sum was still not enough to rescue Greece. In our opinion ${ }^{20}$, this was not because of

\footnotetext{
${ }^{20}$ Krugman (2012, p. 96) supports this opinion. As he wrote, "unfortunately, the Troika systematically lagged far behind [with monetary aid]. Even with this, however, the most extreme cases - Greece, Portugal, and Ireland - remain shut out of private capital markets. So they've been reliant on a series of ad hoc lending programs from the 'troika' of stronger European governments, the ECB, and the International Monetary Fund. Unfortunately, the troika has consistently provided too little money, too late".
} 


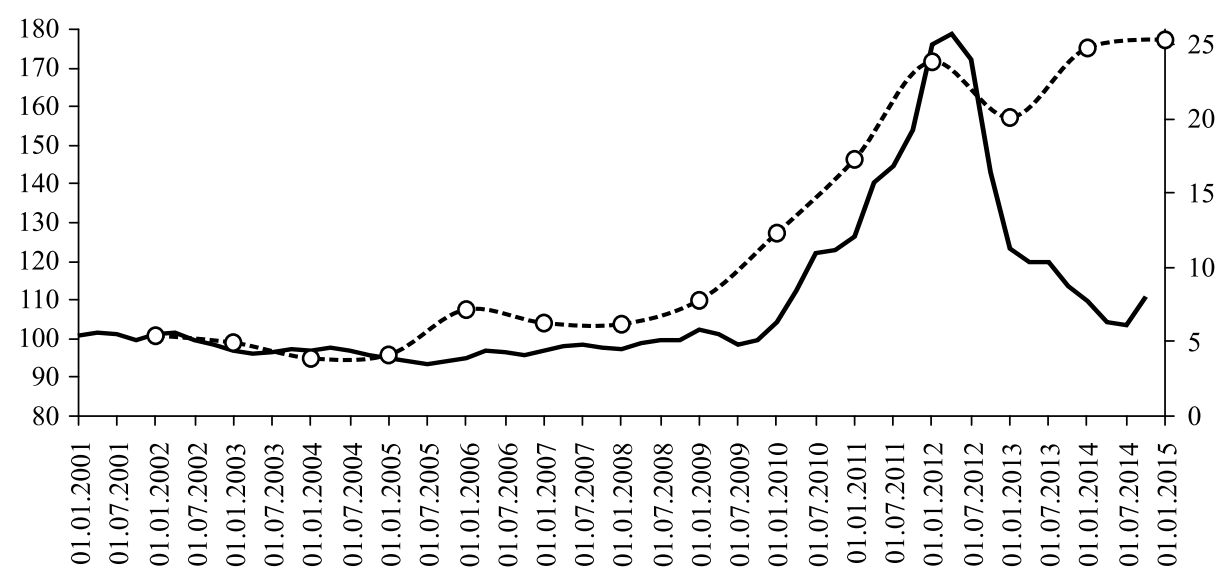

- O- National debt (\% of GDP)

- 10 -year interest rate on government bonds (\%, right-hand scale)

Fig. 2. Greek government bond rate and national debt.

Source: Compiled by the authors based on FRED economic data.

the amount, but because it was spread out over time due to the slow reaction inherent in the European bureaucracy. By the end of 2011, the country's debt-to-GDP ratio was $171 \%$, which posed a threat to the entire Eurozone: Greece's default would have triggered a chain reaction of defaults by borrowing countries. The money allocated by stabilizing institutions and lending countries reduced the debt-to-GDP ratio to $160 \%$ in 2012 . However, the situation again deteriorated. The aforementioned austerity measures were thought to guarantee that the aid provided to the Greek economy would be returned. The idea was simple: through cutting public spending and increasing national income, Greece would be able to repay all loans and its gargantuan debt. In reality, not only did the austerity measures fail to help Greece meet its payment obligations, but they also led to poverty and high unemployment (Papadimitriou et al., 2013). To explain the greatest illusion behind the ineffectiveness of the program initiated by the Troika, we need to look at a graph of the basic GDP components, calculated based on spending (Fig. 3).

Fig. 3 shows the indicators summed up to represent gross domestic product. Because any country typically strives to maximize GDP, all of its components should demonstrate positive trends, or, at least, the growth rate of some indicators should be higher than others. If we follow the trivial rule that any expenses are somebody else's revenues, it becomes clear that decreasing income in the private sector should be accompanied by increasing spending in another national sector to prevent a decline in the country's output. Before the global crisis, GDP growth had been accompanied by a stable rise in private and public spending (up to $10 \%$ annually) and in gross investments (approximately $20 \%$ in 2002, 2005, and 2006), with a trade deficit reaching 30\% in nominal terms. By the end of 2009, all of Greece's macro indicators showed a downward trend. The hardest blow on the economy was the decline in private spending, which was the largest share of GDP (approximately 70\% at the end of 2009). In other words, demand from the private sector dropped sharply, dragging the entire economy down. At the same time, there was no source of investment within the country, while there 


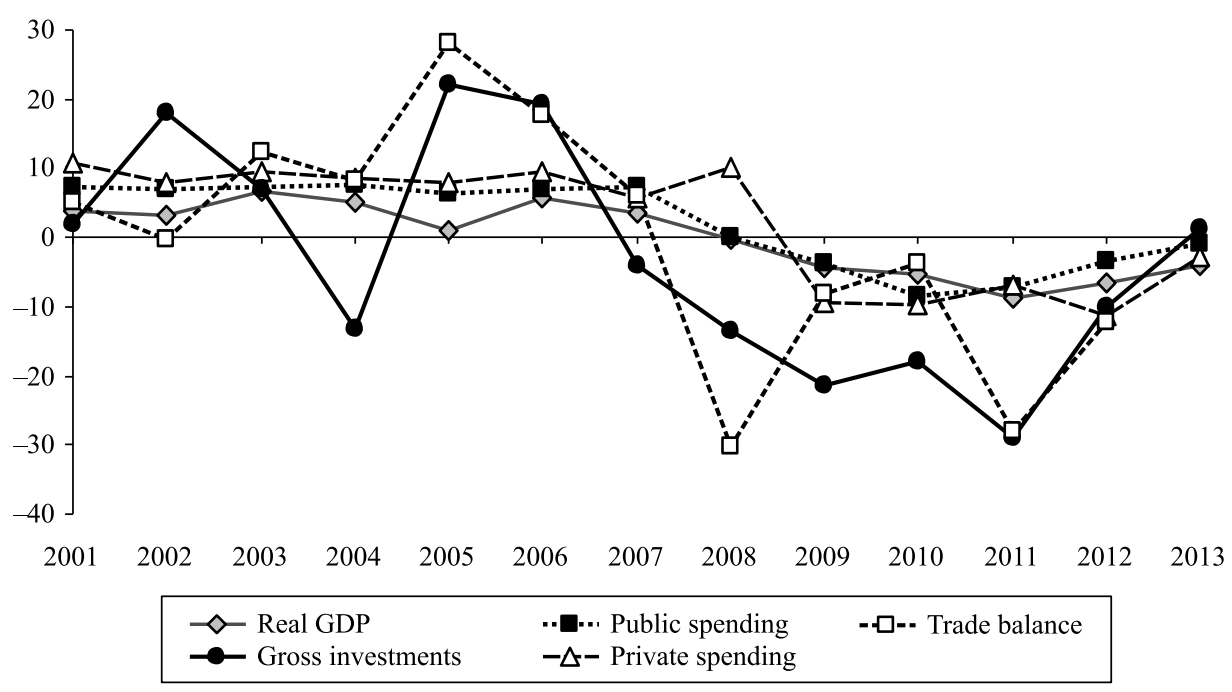

Fig. 3. Basic Greek macroeconomic indicators (\%).

Source: Compiled by the authors based on FRED economic data.

could be no noticeable increase in exports in the short run without currency devaluation. (Keynes is known to have answered the question as to what to do if demand is falling, as far back as in the first half of the 20th century). However, instead of increasing public spending and lowering taxes, the Greek government, compelled by the Troika, did exactly the opposite (Papadimitriou, et al., 2013). On the other hand, the country could not pursue a robust Keynesian policy without the Troika's involvement. First, the enormous debt could not be successfully refinanced; therefore, the Greek government could not increase public spending on its own. Secondly, lower taxes would only feed the already large budget deficit in the short run. Thus, the future of the Greek economy is now in the hands of the Troika and the lending countries, which could either bankrupt the country or continue lending on the austerity measure terms. We can only hope that the creditors will revise their policy and come up with less stringent requirements, while taking more active measures to restore Greece's labor market. Another factor aggravating the situation is the single currency within the Eurozone, which prevents Greece from devaluing its currency to alleviate the debt burden.

The macro indicator trends reviewed above show a slight improvement over the past few years, which superficial analysis would suggest is evidence of an economic recovery. However, unemployment in Greece is $26 \%$ among the adult population (Fig. 4), ${ }^{21}$ whereas youth unemployment is $50 \%$. Can austerity measures help solve the issue of millions being unemployed, secure GDP growth, and rid the economy of the debt burden? The mass protests by the population, the leftists coming to power and the idea of leaving the Eurozone all come as no surprise.

The analysis of public sector indicators and indicators for the economy as a whole revealed certain parallels with the financial instability hypothesis. Applying the hypothesis at the Eurozone level leads to the following conclusions.

\footnotetext{
${ }^{21}$ Regarding the thoughts of Minsky's modern followers on the specific counter-unemployment measures in Greece, see Antonopoulos et al. (2011).
} 


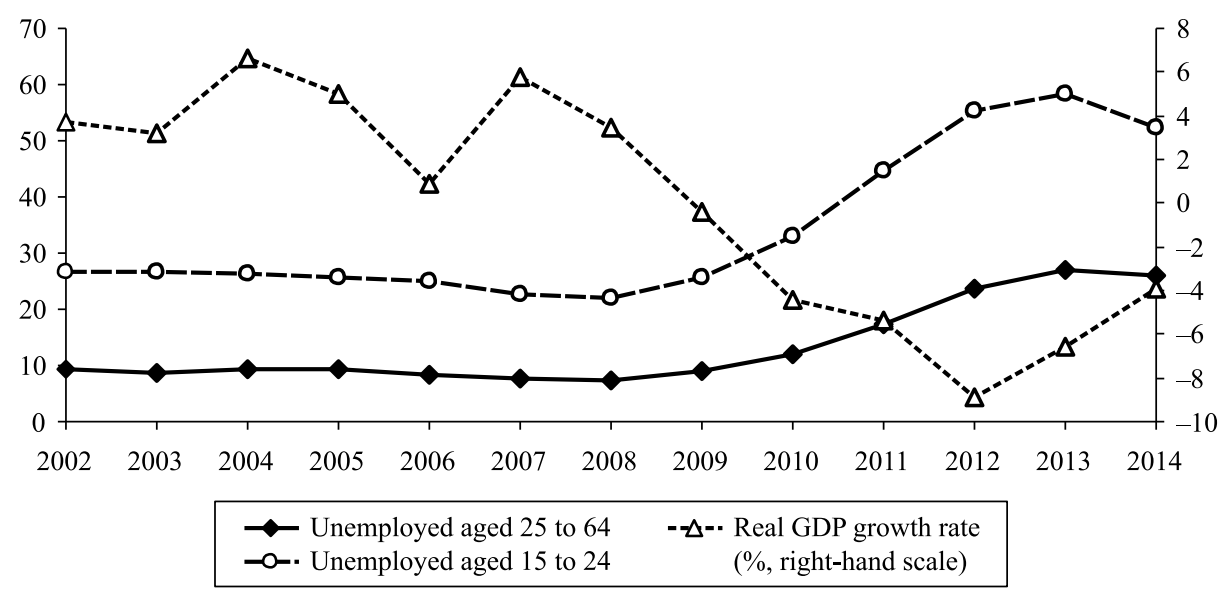

Fig. 4. Unemployment in Greece (\% of the total size of a given age group).

Source: Compiled by the authors based on FRED economic data.

Since its creation, the overall economic growth of the Eurozone has been accompanied by some of the countries lending to others. Greece, which already had a large national budget deficit and increasing public spending at that time, increased its borrowings to finance the deficit. Thus, the Greek public sector can be said to be following a speculative finance scheme.

The global crisis of 2008 and 2009, which precipitated the crisis of confidence in the Eurozone, forced countries to reevaluate lender and borrower risks. This, in turn, made national debt refinancing expensive due to higher interest rates for borrowing countries. Greece faced debt deflation, which raised its national debt to a critical value, putting the country under the threat of default. At this stage, the country's finances took on the features of a Ponzi scheme, which is characteristic of companies that have to borrow simply to stay afloat.

The measures taken by stabilizing institutions were either ineffective or made the problems worse. The coercive policy of austerity measures did not improve the situation as expected.

\section{An analysis of the Greek debt crisis in light of the financial instability hypothesis: The private sector}

We will now apply the financial instability hypothesis in its original form, to analyze how Greek companies changed their financing schemes. Those schemes include hedge, speculative, and Ponzi finance. If the hypothesis is correct, then the reason for such a protracted crisis in Greece has to be the excessive debt in the private sector as a result of superfluous lending during the years of the economic boom.

In our analysis, we used the financial statements for 36 companies from 2001 to 2014. The annual statements for Greek companies were taken from the Bloomberg Terminal. 36 companies were sampled based on the ASE General Index. The composition of the index used in this paper is dated January $1,2005 .^{22}$

$\overline{22}$ The date chosen for downloading the index is not relevant. 
The index includes 60 of the largest Greek companies, weighted in terms of capitalization. In our opinion, using this index will make the sample representative of the country's private sector. The final sample includes 36 companies selected based on the following criteria:

- the company belongs to the real sector;

- we managed to find most of the information about the company for the analysis (over 80\%);

- the company had not been taken over by or merged with another company during the period in question. Bankrupt companies were also included in the sample.

The companies in the sample must be in the real sector, both for theoretical and practical considerations. In his works, Minsky divided the private sector into borrowers and creditors, where the former make investments in fixed capital out of operating profits or borrowed funds, while the latter provide those funds (Minsky, 1986; 1992). Because this analysis attempts to track changes in the type of financing scheme that companies use over time, we are more interested in borrowing companies, which traditionally represent the real sector, than in lending institutions. From a practical point of view, an analysis of the companies' debt burden implies a distinct line between lending institutions and producers of physical and non-physical goods due to differences in their balance sheet structures, or, more precisely, differences in their liability structures.

Applying the financial instability hypothesis in its "pure" form may be difficult in practice, as we cannot deduce from the companies' financial statements which type of finance they use. The statements are also vague as to when a company is actually in need of refinancing and when it is not (except for cases of zero profit). The management of payments under loans and other obligations (of which there are usually several), their refinancing, and new loans taken out for any projects are not recorded in standard accounting statements. This is why the following indicators were suggested for analyzing the type of financing scheme, calculated based on the statements.

Debt-to-Equity Ratio (financial leverage ratio). This ratio reflects a company's funding structure: what amounts of borrowed funds and equity the company uses to conduct its day-to-day business. The standard financial leverage ratio may differ between companies based on the cost of borrowing, the industry, or even the country where the company is located. This study focuses more on changes in financial leverage over time than on its value. To identify the reasons for changes in this ratio, we suggest considering it in tandem with the value of the company's EBIT.

Interest Coverage Ratio:

$$
I R C=\frac{E B I T}{\text { Interest expence }}
$$

where Interest expense means interest payable on the company's borrowings. This ratio lets a financial statement analyst determine the company's ability to meet its obligations to repay loans. According to practical experts, a company that is financially stable and "durable" to external shocks, will have an interest coverage ratio over 3 (Damodaran, 2011; Teplova, 2011). To divide companies by types of financing schemes according to the FIH, this study will use values 
exceeding 3 for companies with hedge finance, between 0 and 3 for speculative finance, and below 0 for Ponzi finance. Division based on 0 is based on the simple observation that a company that has not received a profit during the reporting period cannot service either the interest or the principal of a loan. Meanwhile, a company that received insufficient profit for full coverage can pay back part of its obligations, and take out a new loan for the remaining part.

Having calculated the financial leverage ratios for each company in each reporting period, we found the average value for the period. We then standardized the profit for each company in all periods relative to the average profit for that company across all periods to find the average standardized profit for all companies each fiscal year. By using profit standardization, we leveled out the differences in the scale of company operations and obtained the changes in the average profit (Fig. 5). Fig. 5 shows that average profits for all companies were on the rise until 2008, which corresponds to the economic situation, i.e. the high rate of real GDP growth. At the same time, average financial leverage ratios for the companies also increased from $74.5 \%$ in 2001 to $90.0 \%$ at the end of 2007 , and $109.5 \%$ at the end of 2008 . Based on the FIH, we can conclude that Greek companies actually increased their borrowed capital against the backdrop of rapidly growing profits.

The situation changed abruptly in 2008, with profits falling and financial leverage ratios rising rapidly. It should be noted that in analyzing the national debt-to-GDP ratio, we observed an identical picture; in both cases the indicators increased by approximately 50\%. In 2012, the debt-to-equity ratio declined, which may indicate cheaper financing following the panic on the Eurozone markets and the ability for companies to pay back part of their debts due to higher profits in that year. Concerning our sample, the bankruptcies of three companies with high financial leverage apparently made a certain contribution to the decline. In addition, we could not obtain financial leverage data for all companies over the most recent periods, which is why there is a deviation in the latest years.

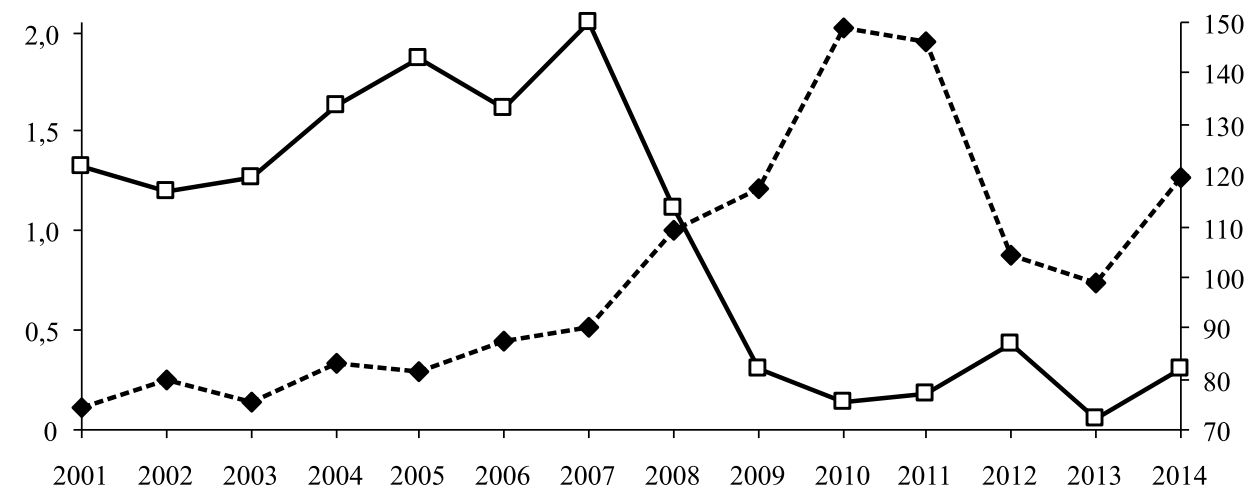

$$
\begin{aligned}
& \text { - Average company profits (standardized, units) } \\
& \text {--- Debt-to-equity ratio (\%, right-hand scale) }
\end{aligned}
$$

Fig. 5. Financial leverage and profits at 36 Greek companies. 


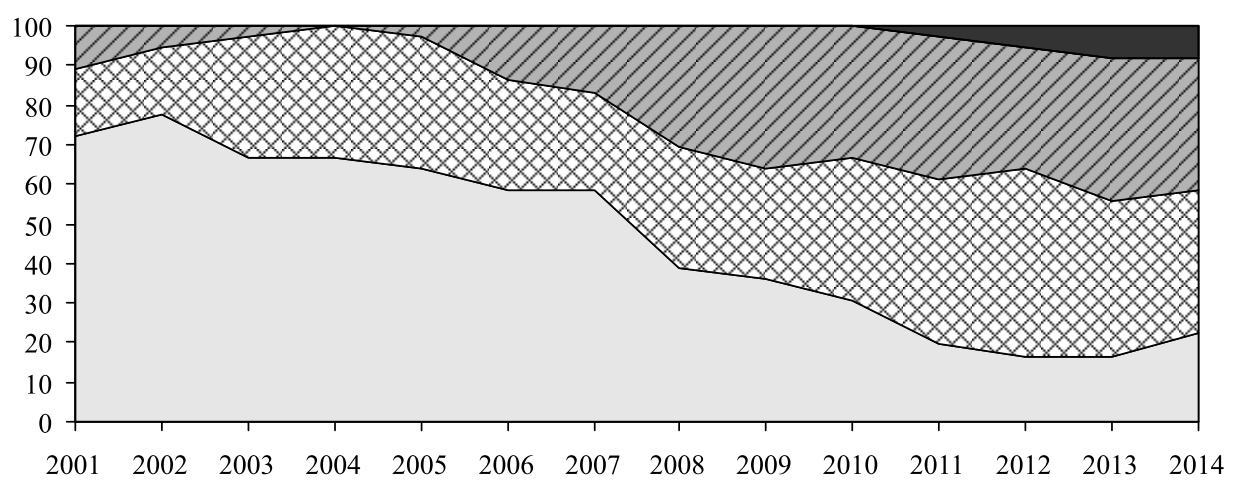

$$
\begin{array}{ll}
\square \text { Hedge finance } & \varnothing \text { Speculative finance } \\
\square \text { Ponzi finance } & \text { Bankrupt companies }
\end{array}
$$

Fig. 6. Number of companies according to the FIH classification (\%).

Source: Compiled by the authors based on their own calculations.

Fig. 6 represents the changes in correlation between the number of companies as per the FIH classification. It should be noted that the companies were divided based on their interest coverage ratios. The shares of companies with different types of financing are expressed as a percentage of the total, which clearly demonstrates the changes in each company's finance schemes. Between 2001 and 2008, the number of companies with speculative and Ponzi finance increased. As seen from the above graph, company profits increased during that period while they increased their borrowings. Evidently, the reason was not the need to refinance debt, but to increase production capacity and the desire to maximize profits. By the end of 2008, the share of companies with fragile financing rose to $61 \%$ of the total number of companies (22 out of 36). Later, as the aggregate demand in the economy fell, companies began to receive lower profits, which led to more cases of Ponzi finance, as shown in the graph. Moreover, the overall recession had an impact on companies that had been previously stable; by 2013 , financially stable companies accounted for $17 \%$ of the sample, which is evidence of the deep recession facing the country. Three companies were officially declared bankrupt.

The above trend in the private sector can be divided into two periods: before and after the crisis. Before the crisis, the number of companies with speculative and Ponzi financing grew. Taking into account the fact that company profits were on the rise at that time, it would be logical to assume that the loans were taken out to expand the business in light of the ongoing favorable economic situation. Drawing a parallel with the FIH, the borrower and lender risks can be said to have decreased in the economy during that period.

While the pre-crisis period can be described by the FIH, the post-crisis period is a logical continuation in the form of debt deflation. Large debts compelled firms to spend less, leading to reduced aggregate demand in the private sector, and since we have already established that public spending was restricted by austerity measures, the entire economy suffered from a sharp decline in demand. In turn, the higher borrower and lender risks caused demand for money to rise, the money supply to contract, and, consequently, the cost of borrowing to increase. The existence of a business is not guaranteed under these conditions. 
Even if a company did not have debt in the beginning, with no demand for its products it would be forced to take out loans or cut costs by selling off its assets and firing its employees. This is a new debt spiral, escape from which is only possible, as previously noted, through government intervention. However, the government is caught up in a similar trap, and Greece has been in recession for seven years as a result.

\section{Conclusion}

We have analyzed the data for both macroeconomic indicators of Greece and those of private sector companies and interpreted them using the tools provided by Minsky's financial instability hypothesis. The analysis of changes in the financial condition of the real sector showed that after joining the Eurozone, companies had actively expanded their activities through borrowing capital. In turn, banks lent willingly to those companies, expecting a stable cash flow from their operations. Thus, a significant portion of Greek companies engaged in speculative and Ponzi financing during the 2000s, becoming financially fragile, in Minsky's terms. The 2008 global crisis caused a revaluation of capital market risks, which had a negative impact on those companies. Falling profits and the high cost of refinancing led to the threat of bankruptcy for financially fragile organizations.

The FIH study at the international level (the Eurozone) enabled events to be rethought which resulted in the debt crisis in a number of European countries. Germany, France, and some other European countries participated in Greece's explosive economic growth, without taking the country's current debt into consideration. The growing uncertainty and economic recession in the Eurozone induced debt crises in southern European countries, particularly a deep recession in Greece. In turn, the austerity measures initiated to resolve the economic problems for Greece and a number of other southern countries turned out to be ineffective, if not detrimental, as proven by the analysis carried out using the Post-Keynesian approach. ${ }^{23}$

Whether Greece leaves the Eurozone or remains in it, the existing provisions need to be revised. A new economic policy is needed that will be able to stop the recession and the bankruptcies and to reduce unemployment. The principles of such a policy should be developed on an alternative theoretical basis to the mainstream (in particular, austerity measures should be approached with far greater criticism). In our opinion, the financial instability hypothesis can be one such basis.

\section{Acknowledgements}

The authors would like to express their gratitude to the anonymous reviewer for valuable comments, most of which were incorporated into the final version of this article.

${ }^{23}$ Our conclusion is in line with the results of a study conducted by Dimitri Papadimitrou, a famous Minsky follower working at the Levy Institute of Economics, and his colleagues; see Papadimitriou et al. (2013). 


\section{References}

Alesina, A., \& Ardagna, S. (2009). Large changes in fiscal policy: taxes versus spending. NBER Working Paper, 15438.

Antonopoulos, R., Papadimitriou, D. B., \& Toay, T. (2011). Direct job creation for turbulent times in Greece. Annandale-on-Hudson, NY: Levy Economics Institute of Bard College.

Arestis, P. (1988). Post-Keynesian theory of money, credit and finance. In P. Arestis (Ed.), PostKeynesian monetary economics: New approaches to financial modelling (pp. 41-71). Aldershot: Edward Elgar.

Arestis, P., \& Glickman, M. (2002). Financial crisis in Southeast Asia: Dispelling illusion the Minskyan way. Cambridge Journal of Economics, 26 (2), 237-260.

Argitis, G., \& Nikolaidi, M. (2014). The financial fragility and the crisis of the Greek government sector. International Review of Applied Economics, 28 (3), 274-292.

Bernanke, B. S., \& Gertler, M. (1990). Financial fragility and economic performance. Quarterly Journal of Economics, 105 (1), 87-114.

Bezemer, D. J. (2001). Post-socialist financial fragility: The case of Albania. Cambridge Journal of Economics, 25 (1), 1-23.

Carvalho, F. J. C. (1992). Mr. Keynes and post Keynesians. Principles of macroeconomics for a monetary production economy. Aldershot: Edward Elgar.

Chick, V. (1992). On money, method and Keynes. Selected essays. London: Macmillan.

Cruz, M., Amann, E., \& Walters, B. (2006). Expectations, the business cycle and the Mexican peso crisis. Cambridge Journal of Economics, 30 (5), 701-722.

Damodaran, A. (2011). Applied corporate finance. Hoboken, NJ: John Wiley \& Sons.

Davidson, P. (1972). Money and the real world. London: Macmillan.

De Paula, L. F., \& Alves, A. J. Jr. (2000). External financial fragility and the 1998-1999 Brazilian currency crisis. Journal of Post Keynesian Economics, 22 (4), 589-617.

Dillard, D. (1948). The economics of John Maynard Keynes. The theory of a monetary economy. N. Y.: Prentice-Hall.

Dufour, M. (2006). Behavioural explorations in a realm of fundamental uncertainty: A reappraisal of the 2000-2001 financial crisis in Turkey. Paper presented at the $35^{\text {th }}$ Annual Conference of the Atlantic Canada Economics Association, Antigonish, Nova Scotia, October 12-14.

Eurostat (2004). Report on the revision of the Greek government deficit and debt figures. Luxembourg. Fisher, I. (1933). The debt deflation theory of great depressions. Econometrica, 1 (4), 337-357.

Greenwald, B. C., \& Stiglitz, J. E. (1993). Financial market imperfections and business cycles. Quarterly Journal of Economics, 108 (1), 77-114.

Herndon, T., Ash, M., Pollin, R. (2014). Does high public debt consistently stifle economic growth? A critique of Reinhart and Rogoff. Cambridge Journal of Economics, 38 (2), 257-279.

IMF (2010). World economic outlook: Recovery, risk, and rebalancing. Washington, DC: International Monetary Fund.

IMF (2012). World Economic Outlook: Coping with high debt and sluggish growth. Washington, DC: International Monetary Fund.

Keynes, J. M. (1937). The "ex ante" theory of the rate of interest. Economic Journal, 46 (186), 663-669.

Keynes, J. M. (1939). The process of capital formation. Economic Journal, 49 (195), 569-574.

Keynes, J. M. (1978). The general theory of employment, interest and money. Moscow: Progress (In Russian).

Kregel, J. (1998). Yes, it did happen again-A Minsky crisis happened in Asia. Jerome Levy Economics Institute Working Papers, 234.

Krugman, P. (2012). End this depression now! N. Y. \& London: W. W. Norton.

Minsky, H. P. (1957). Central banking and money market changes. Quarterly Journal of Economics, 71 (2), 171-187.

Minsky, H. P. (1975). John Maynard Keynes. N. Y.: Columbia University Press.

Minsky, H. P. (1980). Capitalist financial processes and the instability of capitalism. Journal of Economic Issues, 14 (2), 505-524.

Minsky, H. P. (1983). The financial instability hypothesis: An interpretation of Keynes and an alternative to "standard" theory (pp. 282-292). In J. C. Wood (Ed.), John Maynard Keynes. Critical assessments. London: Macmillan. 
Minsky, H. P. (1985). The financial instability hypothesis: A restatement (pp. 24-55). In P. Arestis, \& T. Skouras (Eds.). Post-Keynesian economic theory: A challenge to neoclassical economics. Brighton: Wheatsheaf.

Minsky, H. P. (1986). Stabilizing an unstable economy. New Haven, CT: Yale University Press.

Minsky, H. P. (1992). The Financial instability hypothesis. Jerome Levy Economics Institute Working Papers, 74.

Papadimitriou, D. B., Nikiforos, M., \& Zezza, G. (2013). The Greek economic crisis and the experience of austerity. Annandale-on-Hudson, NY: Levy Economics Institute of Bard College.

Plumer, B. (2012). IMF: Austerity is much worse for the economy than we thought. The Washington Post, October 12.

Pollin, R. (1994). Marxian and Post-Keynesian developments in the sphere of money, credit and finance: Building alternative perspectives in monetary macroeconomics (pp. 97-117). In M. A. Glick (Ed.), Competition, technology and money. Classical and Post-Keynesian perspectives. Aldershot: Edward Elgar.

Reinhart, C. M., \& Rogoff K. (2009). This time is different: eight centuries of financial folly. Princeton, NJ: Princeton University Press.

Rozmainsky, I. V. (2006). Post-Keynesian macroeconomics: Basic perspectives. Voprosy Ekonomiki, 5, 19-31 (In Russian).

Rozmainsky, I. V. (2008). On the methodological foundations of mainstream and heterodoxy in economic theory in the end of the XIX - the beginning of the XXI centuries. Voprosy Ekonomiki, 7, 89-99 (In Russian).

Rozmainsky, I. V. (2009). Minsky's contribution to the economic theory and major causes of crises in late industrial monetary economy. Terra Economicus, 7 (1), 31-42 (In Russian).

Schroeder, S. K. (2002). A Minskian analysis of financial crisis in developing countries. CEPA Working Paper, 2002-09.

Simons, H. (1936). Rules versus authorities in monetary policy. Journal of Political Economy, $44(1), 1-36$.

Teplova, T. V. (2011). Investment. Moscow: Urait (In Russian).

Toporowski, J. (2008). Minsky's 'Induced investment and business cycles'. Cambridge Journal of Economics, 32 (5), 725-737.

Trichet, J.-C. (2010). Interview with La Repubblica. URL: http://www.ecb.europa.eu/press/key/ date $/ 2010 / \mathrm{html} / \mathrm{sp} 100624$.en.html.

Waterfield, B. (2014). Eurozone paves way for third Greek bail-out. The Telegraph. February 3.

Wray, L. R. (1992). Alternative approaches to money and interest rates. Journal of Economic Issues, $26(4), 1145-1178$.

Wray, L. R. (2011). Minsky's money manager capitalism and the global financial crisis. International Journal of Political Economy, 40 (2), 5-20.

Wray, L. R. (2014). From the state theory of money to modern money theory: An alternative to economic orthodoxy. Jerome Levy Economics Institute Working Papers, 792.

Wray, L. R., \& Tymoigne, E. (2008). Macroeconomics meets Hyman P. Minsky: The financial theory of investment. Jerome Levy Economics Institute Working Papers, 543. 